\title{
UHF wind profiler observations of monsoon low-level jet (MLLJ) and its association with rainfall over a tropical Indian station
}

\author{
R. D. RUCHITH, S. M. DESHPANDE and P. ERNEST RAJ \\ Indian Institute of Tropical Meteorology, Dr. Homi Bhabha Road, Pashan, Pune-411008, India \\ Corresponding author: P. Ernest Raj; email: ernestrajp@gmail.com
}

Received: January 14, 2015; accepted: October 20, 2015

\begin{abstract}
RESUMEN
Los datos de alta resolución de perfiles horizontales de viento (zonal y meridional) en la troposfera baja, derivados del perfilador de viento de muy alta frecuencia de Pune, una estación tropical de la India $\left(18^{\circ} 32^{\prime} \mathrm{N}, 73^{\circ} 51^{\prime} \mathrm{E}, 559\right.$ masl), correspondientes a un periodo de tres años (junio de 2003 a mayo de 2006), se utilizaron para estudiar la variabilidad estacional e intraestacional de los vientos. Los vientos muestran una evolución estacional sistemática con comportamientos opuestos en cuanto a su fase en los regímenes de altitud superiores e inferiores a 4-5 km de altura. En la región baja, durante los meses del monzón del suroeste (junio a septiembre) los vientos soplan predominantemente desde el oeste, con un rango máximo de $1.5 \mathrm{a} 3 \mathrm{~km}$, el cual indica la presencia de la corriente monzónica en chorro de baja altitud (MLLJ, por sus siglas en inglés). Poco después de concluido septiembre, los vientos en este rango de altura cambian de dirección y soplan desde el oeste, lo cual se prolonga a los meses de invierno (diciembre a febrero). Por arriba de los $4 \mathrm{~km}$ de altura, los vientos del oeste se observan en la temporada posterior al monzón (octubre a noviembre) y en el invierno. El MLLJ cobra fuerza en los años con temporadas monzónicas normales o intensas. En una escala diaria, durante los meses del monzón del suroeste el viento muestra considerable variabilidad intraestacional, y las temporadas de MLLJ intensos parecen asociarse con la ocurrencia de fuertes aguaceros en la región.
\end{abstract}

\begin{abstract}
High resolution data of horizontal winds profiles (zonal and meridional) in the lower troposphere, derived from a UHF wind profiler at a tropical Indian station, Pune $\left(18^{\circ} 32^{\prime} \mathrm{N}, 73^{\circ} 51^{\prime} \mathrm{E}, 559\right.$ masl) during a 3-yr period (June 2003-May 2006) has been utilized to study seasonal and intra-seasonal variability of winds. Winds display a systematic seasonal evolution with behavior opposite in phase in the two altitude regimes below and above a height of 4-5 km. In the lower region, during the southwest monsoon months (June to September) winds are predominantly westerly with a peak in the $1.5-3.0 \mathrm{~km}$ range indicating the occurrence of the monsoon low-level jet (MLLJ). Soon after September, winds in this height region change from westerly to easterly and these easterlies continue in winter months (December to February). Above a height of $4 \mathrm{~km}$, westerlies are observed during post-monsoon (October to November) and winter periods. The MLLJ is observed to be strong during normal/good monsoon years. On a day-to-day scale during southwest monsoon months, winds exhibit considerable intra-seasonal variability and periods of strong MLLJ seem to be associated with occurrence of spells of rainfall over the region.
\end{abstract}

Keywords: Tropospheric winds, wind profiler, southwest monsoon, monsoon low-level jet.

\section{Introduction}

Wind plays a vital role in atmospheric energetics and it transports heat, mass, moisture and pollutants from one place to another. These transport processes, in turn, affect the local weather including cloud and precipitation processes. Hence, detailed observations of winds with high spatial and temporal resolutions are necessary to understand the processes and their 
interaction with the environment. The ability to understand atmospheric phenomena increases as the ability to observe them with finer resolution in time and space improves. Wind profilers are a powerful tool to obtain vertical profiles of three components of wind velocities at high spatial and temporal resolution, and are widely used not only for atmospheric research but also for operational weather prediction. In clear air, the technique involves backscattering of the UHF/VHF radar signal from turbulent variations in the refractive index and measuring the Doppler shift of the return. Three or more beam directions (non-coplanar) can be used to get a complete wind velocity vector. This technique has been described in a number of reviews including those by Gage and Balsley (1978), Balsley and Gage (1980), Rottger (1980) and Larsen and Rottger (1982). UHF/VHF Wind profiler radars have proven to be excellent tools to study atmospheric winds, associated vertical shears of horizontal winds and various atmospheric turbulence parameters. Several studies are confined to mid and high latitudes (e.g., VanZandt et al., 1978; Smith et al., 1983; Nastrom et al., 1986) and some observational studies are available at low latitudes (e.g., Sato and Woodman, 1982; Tsuda et al., 1985; Jain et al., 1995; Rao et al., 1997).

There are many components of the monsoon system that have significant influence on monsoon variability over the Indian sub-continent. One of them is the strong cross equatorial wind flow in the lower troposphere, which is known as the monsoon low-level jet (MLLJ). It is recognized as one of the important synoptic components of Indian summer monsoon, with a cross equatorial current from the southern Indian Ocean to the central Arabian Sea (Krishnamurti et al., 1976), and provides large moisture supply over land regions (Ordóñez et al., 2012). The MLLJ arises mainly because of thermal gradient between the Asian landmass and surrounding oceans. Initially it is southerly in direction over the south Indian Ocean, but as it crosses the equator and as a result of the Coriolis force, it turns southwesterly as it reaches the Indian subcontinent (Hoskins and Rodwell, 1995). The dynamics involved in the sustaining mechanism of this MLLJ is described in detail by Rodwell and Hoskins (1995). Goswami et al. (1998) have shown the MLLJ is interlinked with active and break phases of the Indian summer monsoon, as its strength and position controls the moisture transport over Indian land mass, and Joseph and Sijikumar (2004) analyzed the intra-seasonal variability of the MLLJ. Using wind profile data from radiosonde/ radio-wind network over India, Joseph and Raman (1966) have provided observational evidence of this westerly low-level jet stream over peninsular India during the southwest monsoon period (June-September). More recently, Kalapureddy et al. (2007) have utilized high-resolution wind observations from lower atmospheric wind profiler (LAWP) data over a tropical Indian station, Gadanki $\left(13.5^{\circ} \mathrm{N}, 79.2^{\circ} \mathrm{E}\right)$ to characterize the diurnal and seasonal features of MLLJ, whose core was observed to be at a height of $1.8 \pm 0.6 \mathrm{~km}$ with a mean jet intensity of about $20 \mathrm{~ms}^{-1}$. From UHF wind profiler measurements over Pune, India wind speeds in excess of $15-20 \mathrm{~ms}^{-1}$ have been frequently observed during the active southwest monsoon phase in July, with a peak wind speed occurring around $2-3 \mathrm{~km}$ (Joshi et al., 2006). Thus the strong low-level westerlies over the current observing station in India (Pune) are representative of the largescale monsoon low-level jet (MLLJ).

High resolution UHF wind profiler observations made over a 3-yr period (June 2003-May 2006) over a tropical Indian station at Pune $\left(18^{\circ} 32^{\prime} \mathrm{N}, 73^{\circ} 51^{\prime} \mathrm{E}\right.$, 559 masl) are used in this work to study the seasonal variation of horizontal winds, the structure of MLLJ and its association with rainfall over the region. A brief description of the wind profiler radar system and data set used here is given initially followed by presentation and discussion of the results.

\section{Wind profiler system and data}

The $404 \mathrm{MHz}$ wind profiler was in continuous operation at Pune for nearly four years since June 2003. The wind data collected during this period has been quality checked and archived for the scientific users' community by the India Meteorological Department (IMD), Pune. The system consists of a dual polarized coaxial collinear antenna array, with both arrays aligned along true N-S and E-W directions. The arrays produce three beams, two of them tilted; one along the east, another along the south and the third beam directed to the zenith. The profiler measures the radial velocities along these three beams by analyzing the observed Doppler shifted signals with the Doppler beam swinging technique. Such a configuration enables simultaneous measurement of all three components (zonal, meridional and vertical) of 
the wind field. The system has height coverage from $1.05 \mathrm{~km}$ to about 6-10 km (upper altitude depending on weather conditions) at height intervals of $300 \mathrm{~m}$. The return signals in the radar system depend on the backscatter through Bragg scattering from turbulent fluctuations in a radio refractive index in the neutral atmosphere, which are caused by clear air density fluctuations and/or by Fresnel scattering. The mean wind at any given height carries these fluctuations/ irregularities and thus the latter (and hence the backscatter signal) becomes a tracer of mean wind velocity at that height. The wind profilers at VHF/ UHF bands also observe Rayleigh scattering from hydrometeors during precipitation along with Bragg scattering and Fresnel reflection/scattering. One set of vector wind profiles is obtained in about $6 \mathrm{~min}$, depending on the dwell time utilized for each radial beam measurement. The radial velocity values for each beam obtained for a given range bin, over the total observational period, are passed through a process of consensus averaging, which helps to eliminate to a large extent the effects of transient interfering signals, outliers and random "spiky noise". The radial velocities are sampled at 2-6 s intervals, depending on the system pulse repetition period, number of coherent and incoherent integrations, and number of FFT points. The radial velocities after passing through the process of consensus averaging are then used to calculate the zonal, meridional and vertical wind velocities, representative of the mean wind in the hour of the observation. A vector wind profile is thus obtained typically in 5 to $6 \mathrm{~min}$. The technical specifications of the Pune wind profiler system and details, which include signal processing, data quality control and preliminary validation of the wind profiler data products with other conventional instruments, have been given in Pant et al. (2005). Some results of time-height variations in vertical winds obtained from the same wind profiler are discussed by Deshpande and Ernest Raj (2008) and also a case study of a thunderstorm event has been described in literature (Deshpande and Ernest Raj, 2009).

In the present study, horizontal wind (comprising zonal and meridional components) measurements derived from the Pune wind profiler during the 3-yr period (June 2003-May 2006), have been used to investigate and discuss the monthly and seasonal mean variation of winds in the lower troposphere, the seasonal evolution of the low-level jet, and the in- tra-seasonal and inter-annual variations in the MLLJ. As per the observational protocol of the wind profiler operation, during the southwest monsoon months of June-September, hourly averaged profiles, numbering eight each day, at 3-h intervals during day and night (i.e., at 02:00, 05:00, 08:00, 11:00, 14:00, 17:00, 20:00, and 23:00 LT) are available. But during the other months of the year, they are available for daytime only (i.e., at 08:00, 11:00, 14:00, and 17:00 LT). Thus the 3-yr data set used in the present study encompasses a total of 4393 vertical profiles (3470 profiles only during daytime hours) in the height range of 1.05 to around $10.05 \mathrm{~km}$ measured on about 996 observational days with the $404 \mathrm{MHz}$ UHF radar over the tropical station Pune. As the horizontal wind data at heights above $8 \mathrm{~km}$ during the 3 -yr observation period for monthly and seasonal averaging was found to be sparse, vertical profiles from 1.05 to $8 \mathrm{~km}$ alone have been used for further analysis and discussion. Moreover, for uniformity only daytime data have been used to get daily mean profiles (i.e., average of four profiles between 08:00 and 17:00 LT) for the entire 3-yr data, from which monthly and seasonal mean vertical profiles are obtained. For investigating intra-seasonal variations during the SW monsoon season (June-September) alone, all the eight profiles obtained during daytime and nighttime have been used to estimate daily means. The results are presented and discussed in the following section.

\section{Results and discussion}

Daily mean data are grouped into the main four seasons, namely, pre-monsoon (March-May), southwest monsoon (June-September), post-monsoon (October-November) and winter (December-February) seasons. The seasonal mean profiles of zonal and meridional winds are obtained from daily means and are shown plotted in Figures 1 and 2, respectively. It is seen that the zonal wind shows clear seasonal variation. During the pre-monsoon, winds are westerly at almost all heights up to $9 \mathrm{~km}$ but with small magnitude. During the following season (monsoon), a low-level wind maximum is seen around $2.5 \mathrm{~km}$ above ground level with a peak speed of about $6 \mathrm{~ms}^{-1}$ on a seasonal mean scale. Westerlies extend up to $7 \mathrm{~km}$ with a reversal in wind direction to easterlies above. The existence of a low-level westerly maximum in the seasonal mean indicates the existence of the MLLJ in SW monsoon months over Pune. But 

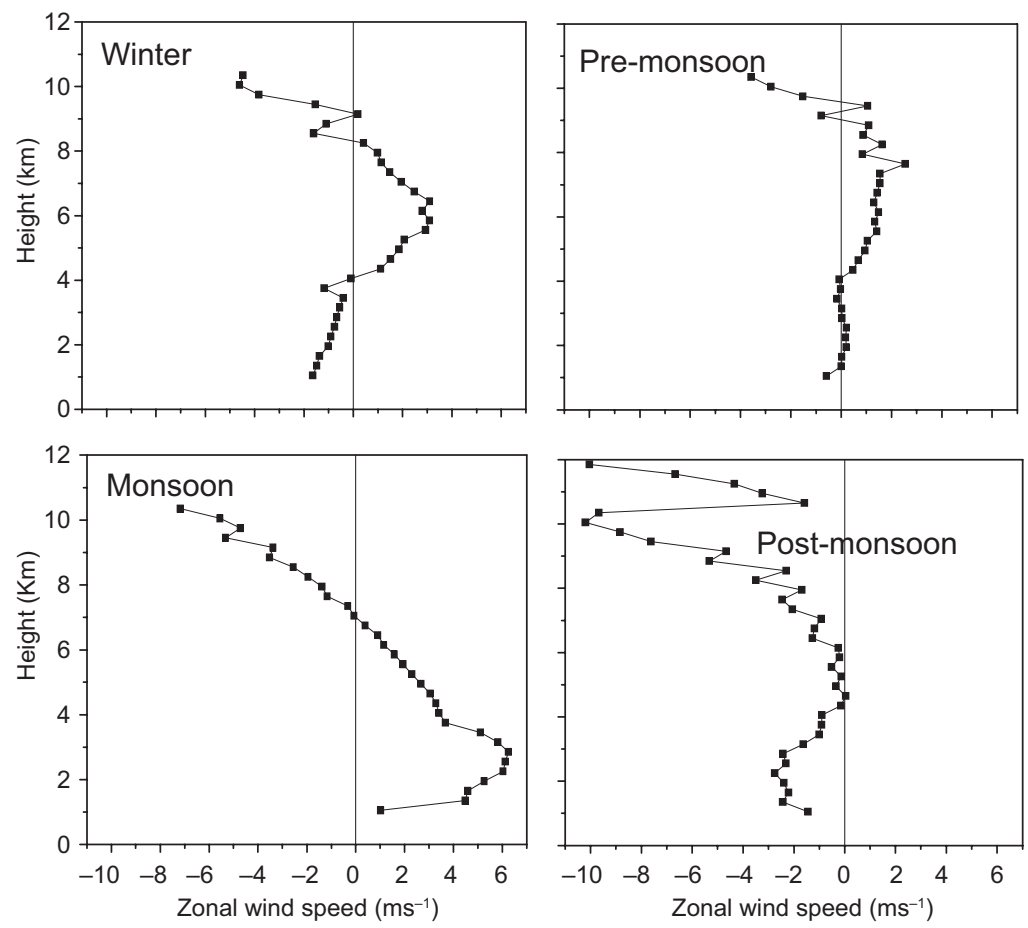

Fig. 1. Seasonal mean vertical profiles of zonal wind speed for the four seasons, namely winter (December-February), pre-monsoon (March-May), monsoon (June- September), and post-monsoon (October-November) for the 3-yr period (June 2003-May 2006).
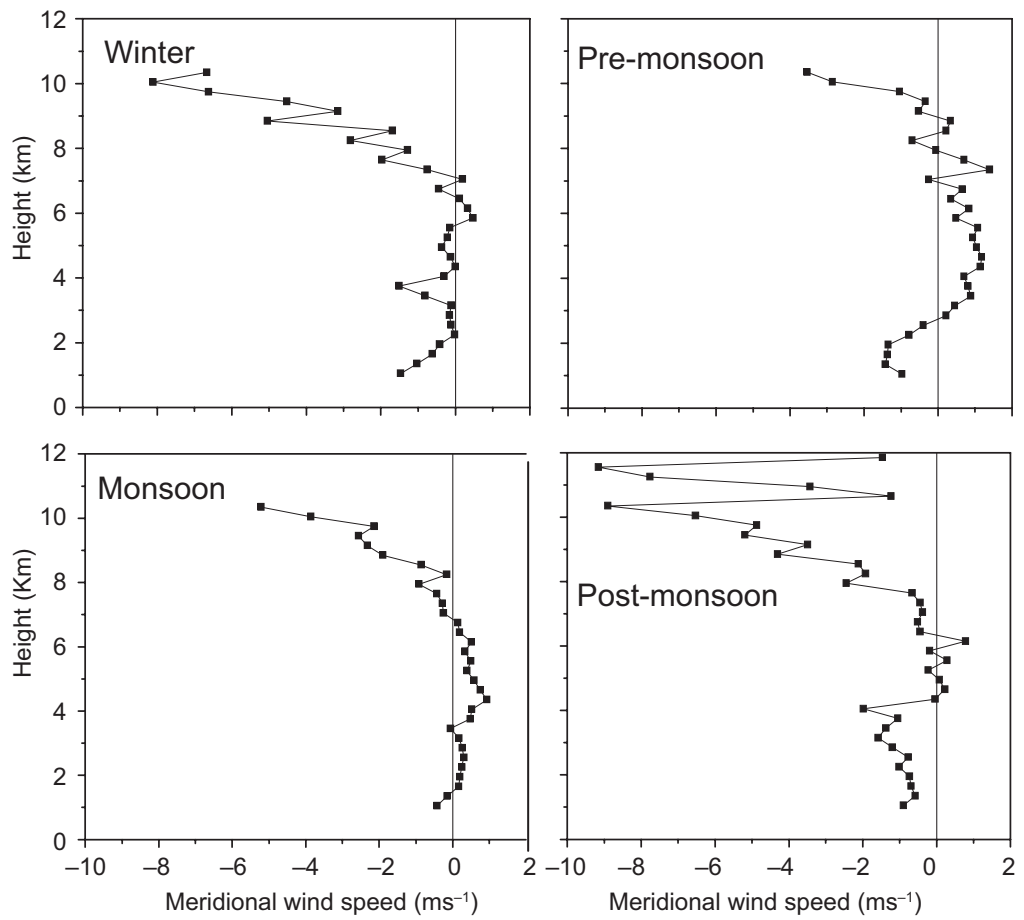

Fig. 2. Seasonal mean vertical profiles of meridional wind speed for the four seasons, namely winter (December-February), pre-monsoon (March-May), monsoon (June- September), and post-monsoon (October-November) for the 3-yr period (June 2003-May 2006).

in the post-monsoon season the vertical structure completely changes. During this short two-month period, lower tropospheric winds are easterly but with small magnitude. In winter also the surface level winds are easterly up to an altitude of about $4 \mathrm{~km}$.
A striking feature during winter is the presence of a mid-tropospheric westerly maximum with a magnitude of around $4 \mathrm{~ms}^{-1}$ on a seasonal scale at a height of around $6 \mathrm{~km}$. This may be due to the effect of a subtropical westerly jet stream which has its 
maximum intensity in the subtropical regions at height level of $10 \mathrm{~km}$. Thus the analysis of seasonality of zonal winds in the lower troposphere brings out two noticeable features; the time evolution of low level westerly maxima during monsoon period, associated with the MLLJ over the tropical Indian region, and the presence of a mid level westerly maxima which may be due to the influence of a subtropical westerly jet stream during winter season.

The magnitude of the meridional wind (Fig. 2) is less compared to that of zonal wind, especially in the lower troposphere and its seasonal variation is also not prominent as seen in the zonal wind. During the pre-monsoon, surface winds are northerly up to $3 \mathrm{~km}$ and southerlies prevail in the 3-8 km range; thereafter, wind turns northerly again. Winds are predominantly southerly up to $7 \mathrm{~km}$, though weak in magnitude, during the SW monsoon season. During the post-monsoon season northerly winds are prevailing almost throughout the lower troposphere. In the winter period winds are weak and fluctuate between northerly and southerly.

To study the variations in the vertical structure of zonal winds on a monthly mean scale and their month-to-month evolution, monthly mean profiles are obtained from January to December for the 3-yr period (June 2003- May 2006) and shown plotted in Figure $3 \mathrm{a}, \mathrm{b}$, c. Monthly mean zonal winds over this location show that winds are easterly up to $4 \mathrm{~km}$ and westerly above this height from January to March. During January a westerly maxima is seen around $6 \mathrm{~km}$ with a mean magnitude of $7 \mathrm{~ms}^{-1}$, and this mid-level westerly maxima persists until April. After that it weakens and then the MLLJ evolves during the SW monsoon months from June to September. This MLLJ shows relatively higher magnitude (8-9 $\left.\mathrm{ms}^{-1}\right)$ in July and August, and then it loses its strength in the post-monsoon and disappears by October. Tropospheric winds are westerly and small in magnitude in April, but in May winds are westerly up to $3 \mathrm{~km}$ and above this height easterlies prevail. Westerly winds extend up to $8 \mathrm{~km}$ during June, July, and August with considerable magnitude in the lower level. During October and November easterlies prevail in the entire lower troposphere with small magnitudes of wind speed. During December easterlies prevail up to $5 \mathrm{~km}$ with a westerly wind regime at altitudes between 6 and $8 \mathrm{~km}$, however with small magnitude of winds. Thus, from the analysis of monthly mean profiles of zonal winds two prominent features are noticed. One is the time evolution of the MLLJ on a monthly scale, which starts in the month of April, reaches its maximum intensity in July-August and then completely disappears by October. The other is the time evolution of a mid-level westerly maximum (6-8 km) which starts appearing in December, reaches its maximum intensity during January and weakens thereafter. In comparison to the zonal winds, the variability of meridional winds on a monthly scale is observed to be small and hence not shown here.

In order to notice the time-height evolution of the zonal components of wind in the tropical lower troposphere and its year-to-year variability, the individual monthly mean profiles for the 36-month period (June 2003-May 2006) are taken to plot the time-height cross-section shown in Figure 4. The $x$-axis shows the month number starting from June 2003. Positive values (pink shaded regions) in the figure indicate that winds are westerly. It is seen that there exists a systematic pattern of variation on monthly mean scale which is repeated yearly. Seasonal variation of zonal winds shows two altitude regimes with a transition at an altitude of around 4-5 km. Both altitude regions show a clear alternating pattern of westerly and easterly winds. During the SW monsoon months (June-September, i.e. months number 1-4, 13-16, 25-28 in Fig. 4) winds are predominantly westerly in the lower troposphere with strong westerlies in the 1.5 to $3.0 \mathrm{~km}$ range. The transition in this lower region from westerly to easterly takes place immediately after September and easterlies also continue to prevail in winter months. Above an altitude of $4 \mathrm{~km}$, an opposite seasonal behavior can be noticed. Here westerlies are observed in post-monsoon and winter months. Another interesting feature is that low-level westerlies sometimes extend into the upper level during monsoon months. A year-to-year variability in this seasonal behavior is also evident. The seasonal (June-September) mean MLLJ core speeds during the years 2003, 2004 and 2005 were calculated to be $9.24,7.78$, and $9.45 \mathrm{~ms}^{-1}$, respectively. Thus the low-level westerly maximum (the MLLJ core) seems to be relatively stronger in intensity during 2003 and 2005 , compared to 2004. Reports of the IMD on the performance of the southwest monsoon over India indicate that 2003 and 2005 were normal monsoon years and that 2004 is a below normal year. That is, both on an all-India scale and over the observation 
a)
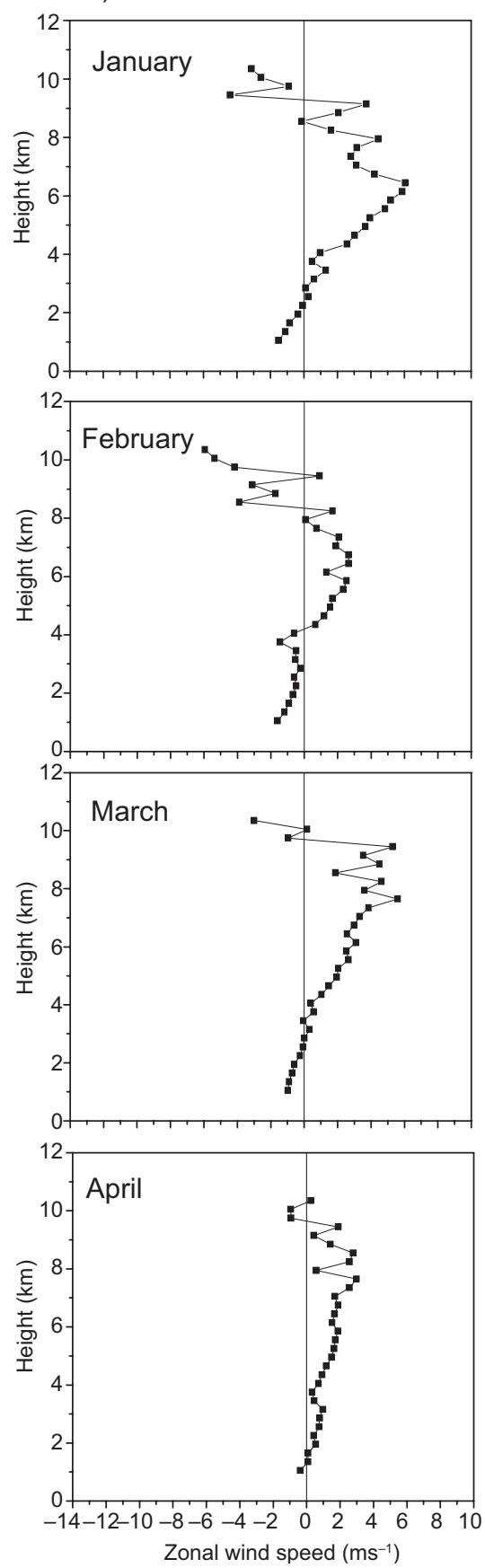

b)
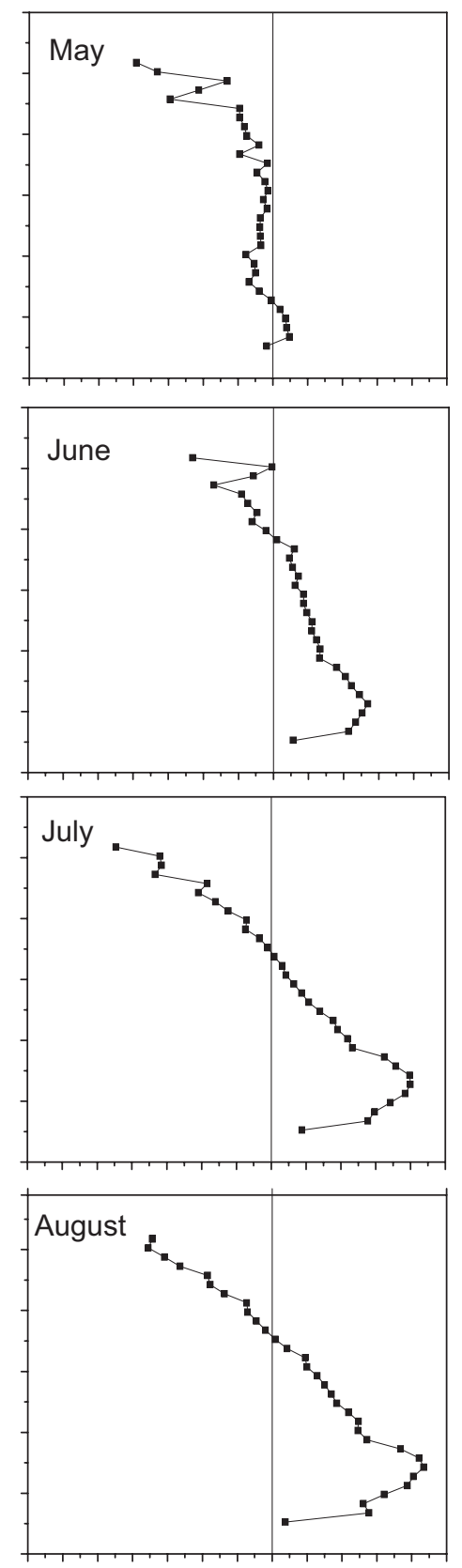

$-14-12-10-8-6-4-2 \quad 0 \quad 2 \quad 4 \quad 6 \quad 8 \quad 10$ Zonal wind speed $\left(\mathrm{ms}^{-1}\right)$ c)
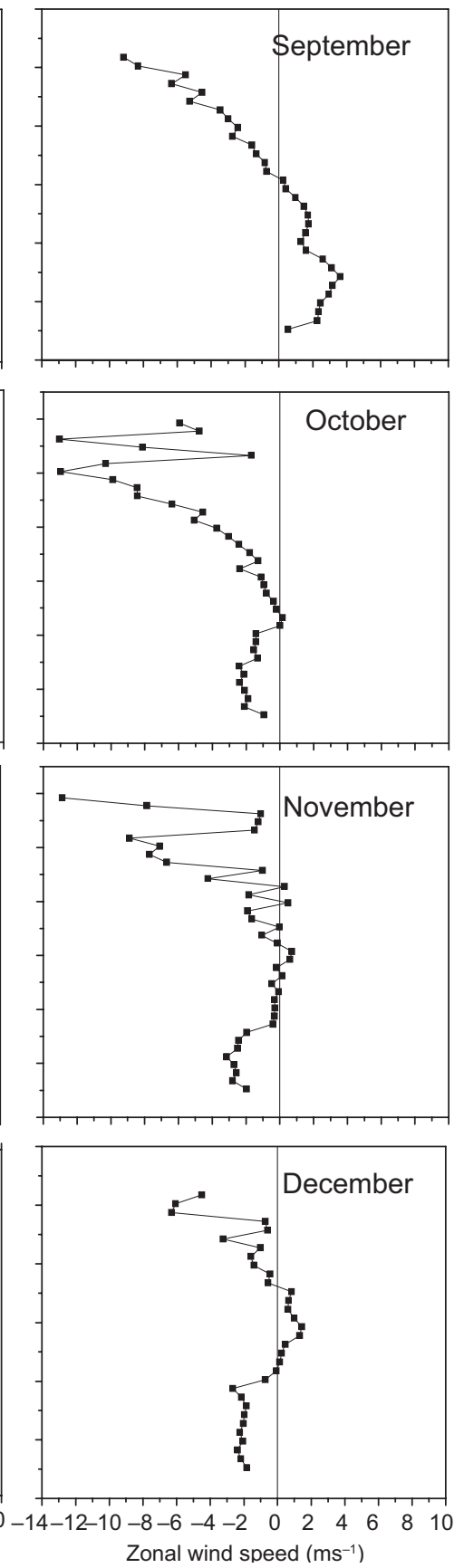

Fig. 3. (a) Monthly mean vertical profiles of zonal wind speed for January-April during the 3-yr period (June 2003-May 2006). (b) Same as in (a) but for May-August. (c) Same as in (a) but for September-December.

region, seasonal rainfall during June-September 2004 was below the long-term normal value. Thus, on a seasonal scale it can be said that strong MLLJ conditions can lead to good/normal rainfall during the monsoon season. The mid-level (5 to $7 \mathrm{~km}$ ) westerly maximum also exhibits a variation. It is strong and narrow in duration during the 2003-2004 winter seasons but is weaker in magnitude during the 2004-2005 and 2005-2006 winter seasons.

To examine in more detail the intra-seasonal variability of the zonal wind component on a daily scale, and also to analyze its relationship with monsoon 


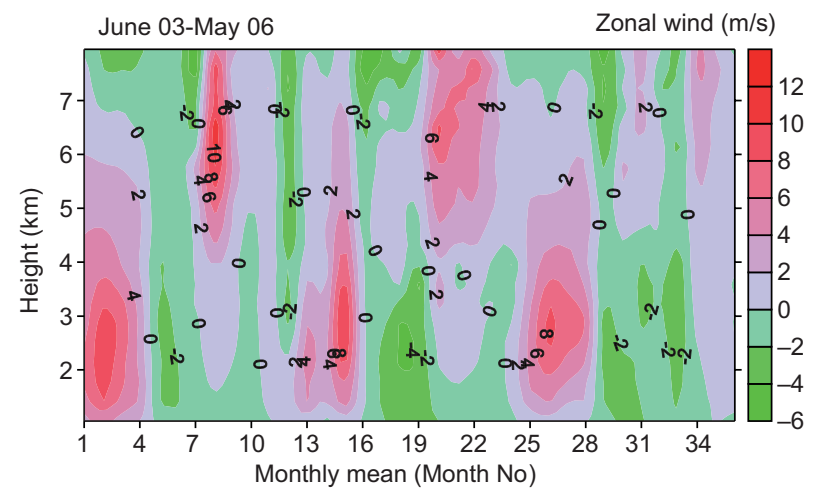

Fig. 4. Time-height cross-section of monthly mean time-series of zonal wind speed from June 2003 to May 2006.

precipitation, daily average zonal wind profiles during the months of June-September for all the three years (2003, 2004, 2005) are shown plotted as time-height cross-sections in Figure 5a, b, c. Daily total rainfall $(\mathrm{mm})$ for Pune station (obtained from daily weather reports of the IMD, Pune) is also shown overlaid as line plots in these figures for a qualitative comparison. Significant intra-seasonal variability can be seen in lower tropospheric zonal winds. During the monsoon season of 2003 there are several episodes of stronger westerlies (Fig. 5a) spread throughout the season. On almost all days during the monsoon season, MLLJ is present having a jet core in the $2-4 \mathrm{~km}$ height range. The zonal wind speed in the jet core even reaches up to $18 \mathrm{~ms}^{-1}$. This MLLJ seems to have a role in the modulation of monsoon intra-seasonal oscillation. Another interesting feature is that the vertical extent of the low-level westerly maxima sometimes even intrudes up to $8 \mathrm{~km}$. On average, it extends up to $6 \mathrm{~km}$ with a speed of $10-12 \mathrm{~ms}^{-1}$. However, during the monsoon seasons of 2004 and 2005 (Fig. 5b, c), there are distinctly separate episodes of few days duration (for example three in 2005) when a strong westerly flow occurs over this region. It is interesting to see that during the monsoon season in all three years, whenever there is a strong MLLJ, occurrence of precipitation over the station is noticed (peaks in the rainfall curves). During 2003 even small peaks in rainy days coincide with stronger MLLJ. A heavy rain spell took place from days 52 to 58 when the zonal wind speeds in the $2.5-3.5 \mathrm{~km}$ altitude range were above $16 \mathrm{~ms}^{-1}$. During 2004 two heavy rain spells occurred over Pune on June 12 to 20, and from July 28 to August 22, which were accompanied by strong westerlies (around $18 \mathrm{~ms}^{-1}$ ).
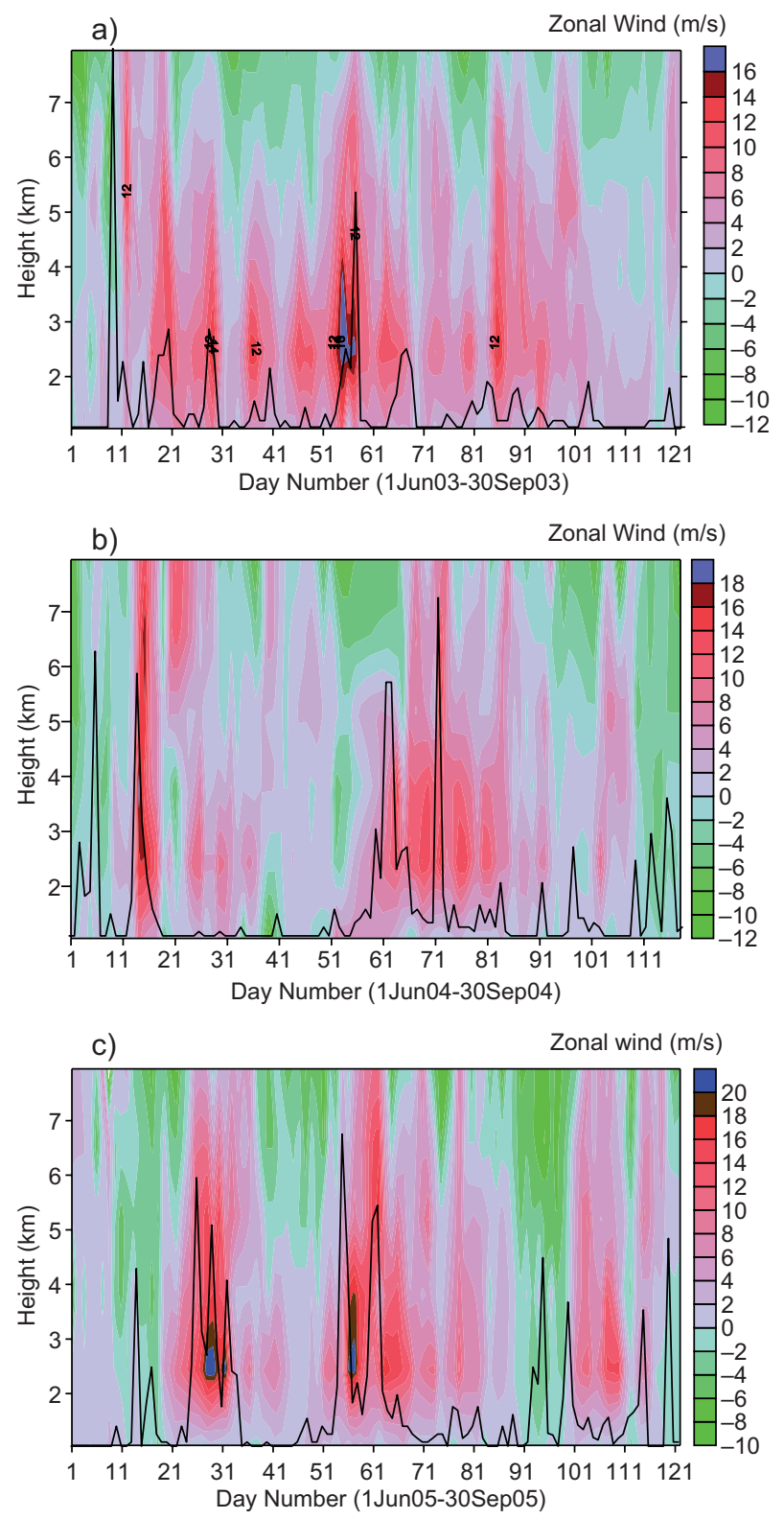

Fig. 5. (a) Time-height cross-section of daily mean time-series of zonal wind speed for the period June 1 to September 30, 2003 along with daily rainfall (solid line) over Pune station. (b) Same as in (a) but for the period June 1 to September 30, 2004. (c) Same as in (a) but for the period June 1 to September 30, 2005.

Again, in the monsoon season of 2005, three heavy rain spells occurred (June 22-July 2, July 24-August 10, September 9-20), and strong MLLJ with a jet core magnitude as high as $20 \mathrm{~ms}^{-1}$ on a daily mean scale were observed during these episodes. A simple quantitative analysis carried out showed that during the days in which precipitation values were 
larger than $10 \mathrm{~mm}$, the low-level westerly maxima (MLLJ core speed) had mean speeds of $14.5,13$, and $15.3 \mathrm{~ms}^{-1}$, respectively during the years 2003, 2004 and 2005, larger than their mean seasonal values. Thus, precipitation spells/episodes during active monsoon conditions are due to the large-scale zonal flow, closely related to a strong MLLJ. However, one can also notice sharp rainfall peaks (of 2-3 days duration) during the first half of June and the last week of September which do not seem to be accompanied by strong westerlies. This may be due to the fact that the monsoon flow is weak or has not yet settled in the region by the first week of June and the precipitation that occurred during this period may be due to strong local convection (the so-called pre-monsoon and post-monsoon thunderstorms). The normal onset date of southwest monsoon over the Pune region is June 6 as per long-term climatology.

\section{Conclusions}

Horizontal wind profile data obtained from an UHF wind profiler at the tropical Indian station of Pune during the 3-yr period June 2003-May 2006 has been utilized to study seasonal and intra-seasonal variability of winds in the lower troposphere. Winds display a predominant systematic seasonal evolution in two altitude regimes, having a transition at an altitude of around $4-5 \mathrm{~km}$. In the lower region, during the southwest monsoon months (June to September) winds are predominantly westerly with a peak around the $1.5-3 \mathrm{~km}$ range, indicating the presence of MLLJ. Change over from westerly to easterly in this height region takes place soon after the month of September (when SW monsoon mostly withdraws from the Indian subcontinent) and easterlies continue in winter months. Above $4 \mathrm{~km}$ height, the behavior of winds is quite opposite in direction. Here westerlies are observed during the post-monsoon and winter periods. The MLLJ is stronger during normal/good monsoon years. It is interesting to see that on a dayto-day scale, a stronger MLLJ is closely associated with occurrence of rainfall over the station and this is consistently observed during all the three years.

\section{Acknowledgments}

Authors are grateful to the Director of the Indian Institute of Tropical Meteorology, Pune, for his encouragement. They also wish to thank the IMD, Pune, for its support in acquiring and archiving the wind profiler data. One of the authors (RDR) would like to gratefully acknowledge CSIR, Government of India, for providing a research fellowship to undertake this work.

\section{References}

Balsley B. B. and K. S. Gage, 1980. The MST radar technique: Potential for middle atmospheric studies. Pure Appl. Geophys. 118, 452-493.

Deshpande S. M. and P. Ernest Raj, 2008. Mean vertical motions and their time-height variations in the lower troposphere obtained from UHF wind profiler at Pune, a tropical Indian station. J. Geophys. Res. 113, 1-11, D07104, doi:10.1029/2007JD008704.

Deshpande S. M. and P. Ernest Raj, 2009. UHF Wind Profiler Observations during a tropical pre-monsoon thunderstorm - A case study. Atmos. Res. 93, 179-187, doi:10.1016/j.atmosres.2008.10.006.

Gage K. S. and B. B. Balsley, 1978. Doppler radar probing of the clear atmosphere. Bull. Amer. Meteor. Soc. 59, 1074-1093.

Goswami B. N., D. Sengupta and G. Suresh Kumar, 1998. Intraseasonal oscillations and interannual variability of surface winds over the Indian monsoon region. $P$. Indian A. S. Earth 107, 45-64.

Hoskins B. J. and M. J. Rodwell, 1995. A model of the Asian summer monsoon. Part I: The global scale. $J$. Atmos. Sci. 52, 1329-1340.

Jain A. R., Y. Jaya Rao, P. B. Rao, V. K. Anandan, S. H. Damle, P. Balamuralidhar, A. Kulakarni and G. Viswanathan, 1995. Indian MST radar, 2. First scientific results in ST mode. Radio Sci. 30, 1139-1158.

Joseph P. V. and P. L. Raman, 1966. Existence of low-level westerly jet-stream over peninsular India during July. Indian J. Meteorol. Phys. 17, 407-410.

Joseph P. V. and S. Sijikumar, 2004. Intraseasonal variability of the low-level jet stream of the Asian summer monsoon. J. Climate, 17, 1449-1458.

Joshi R. R., S. M. Deshpande, N. Singh, S.H. Damle and G.B. Pant, 2006. UHF wind profiler observations of monsoon low level jet over Pune, India. J. Radio Space Phys. 35, 345-359.

Kalapureddy M. C. R., D. N. Rao, A. R. Jain and Y. Ohno, 2007. Wind profiler observations of a monsoon low-level jet over a tropical Indian station. Ann. Geophys. 25, 2125-2137.

Krishnamurti T. N., J. Molinari and H. L. Pan, 1976. Numerical simulation of the Somali jet. J. Atmos. Sci. 33, 2350-2362. 
Larsen M. F. and J. Rottger, 1982. VHF and UHF Doppler radars as tools for synoptic research. Bull. Amer. Meteor. Soc. 63, 996-1008.

Nastrom G. D., K. S. Gage and W. L. Ecklund, 1986. Variability of turbulence, 4-20 km, in Colorado and Alaska from MST radar observations. J. Geophys. Res. 91, 6722-6734.

Ordóñez P., P. Ribera, D. Gallego and C. Peña-Ortiz, 2012. Major moisture sources for Western and Southern India and their role on synoptic-scale rainfall events. Hydrol. Process. 26, 3886-3895, doi:10.1002/hyp. 8455.

Pant G. B., R. R. Joshi, S. H. Damle, S. M. Deshpande, N. Singh, R. D. Vashistha, P. Neekhra, J. V. Chande, A. A. Kulkarni and J. S. Pillai, 2005. Wind profiler and radio acoustic sounding system at IMD, Pune: Some preliminary results. Current Sci. 88, 761-769.

Rao D. N., P. Kishore, T. Narayana Rao, S. Vijaya Bhaskara Rao, K. Krishna Reddy, M. Yarraiah and M. Hareesh, 1997. Studies on refractivity structure constant, eddy dissipation rate and momentum flux at tropical latitude. Radio Sci. 32, 1375-1389.
Rodwell M. J. and B. J. Hoskins, 1995. A model of the Asian summer monsoon. Part II: Cross-equatorial flow and PV behavior. J. Atmos. Sci. 52, 1341-1356.

Rottger J., 1980. Structure and dynamics of the stratosphere and mesosphere revealed by VHF radar investigations. Pure Appl. Geophys. 118, 494-527.

Sato T. and R. F. Woodman, 1982. Fine altitude resolution observations of stratospheric turbulent layers by the Arecibo 430-MHz radar. J. Atmos. Sci. 39, 2546-2552.

Smith S. A., G. J. Romick and K. Jayaweera, 1983. Poker Flat MST observations of shear-induced turbulence. J.Geophys. Res. 88, 5265-5271.

Tsuda T., K. Hirose, S. Kato and M. P. Sulzer, 1985. Some finding on correlation between the stratospheric echo power and the wind shear observed by the Aericibo UHF radar. Radio Sci. 20, 1503-1508.

VanZandt T. E., J. L. Green, K. S. Gage and W. L. Clark, 1978. Vertical profiles of refractivity turbulence structure constant: Comparison of observations by the sunset radar with a new theoretical model. Radio Sci. 13, 819-829. 